Jurnal Ilmu Ilmu Agribisnis: Journal of Agribusiness Science, 9(2), Mei 2021

\title{
ANALISIS PENDAPATAN DAN RISIKO USAHATANI CABAI MERAH DI KECAMATAN WAY SULAN KABUPATEN LAMPUNG SELATAN
}

\author{
(Income and Risk Analysis of Red Chili Farming In Way Sulan Sub-district of South Lampung Regency) \\ Dian Febriany Anugrah, Bustanul Arifin, Ani Suryani \\ Jurusan Agribisnis, Fakultas Pertanian, Universitas Lampung, Jl. Prof. Dr. Soemantri Brojonegoro No. 1, \\ Bandar Lampung, 35145, e-mail : bustanul.arifin@fp.unila.ac.id
}

\begin{abstract}
This research aims to assess the income of red chili farming, the amount of risk faced by red chili farmers, and the correlation between risk and income accepted by the red chili farmers. The study was conducted in Way Sulan Sub-district of South Lampung Regency. The total samples were 56 farmers drawn using a simple random sampling method. The data were collected in March - April 2019 using questionnaires. The first aim was analyzed using the revenue-cost ratio $(R / C)$, which is the comparison between total revenue and total cost. The second aim was analyzed by risk analysis using coefficient variation $(C V)$ and the lower limit $(L)$ on five planting seasons. The third aim was analyzed by Product Moment Pearson correlation. This research results showed that the red chili farming income was profitable because of $R / C>1$. Risk calculation on five planting seasons results showed that the value of $C V<0,50$ and $L>0$, meaning that red chili farming was still profitable in any level of risk. There was positive correlation between the amount of risk and income. It means that the higher level of expected income, the higher level of risk received by farmers.
\end{abstract}

Key words: income, red chili, risk

\section{PENDAHULUAN}

Cabai merah merupakan salah satu komoditas hortikultura jenis sayuran yang memiliki nilai ekonomi tinggi dan mempunyai daya adaptif tinggi, karena dapat tumbuh baik di dataran rendah maupun dataran tinggi. Selain itu, permintaannya selalu tinggi, sehingga komoditas cabai merah potensial untuk dikembangkan.

Pemanfaatan cabai merah dalam sektor industri pangan mempunyai potensi yang sangat besar. Adanya tren bisnis online mendorong meningkatnya pemanfaatan cabai merah untuk industri makanan. Salah satu tren di Indonesia yaitu mewabahnya berbagai restoran yang menyediakan menu makanan dengan berbagai level kepedasan.

Provinsi Lampung merupakan salah satu daerah di Indonesia yang berpotensi untuk melakukan usahatani cabai merah. Berdasarkan data BPS Provinsi Lampung (2014 - 2018) selama lima tahun terakhir, produktivitas cabai merah di Provinsi Lampung berfluktuasi, secara berturutturut yaitu 5,53 ton/ha, 7,38 ton/ha, 19,48 ton/ha, 8,23 ton/ha, dan 6,56 ton/ha. Adanya fluktuasi produktivitas disebabkan naik turunnya produksi dan luas lahan selama lima tahun terakhir. Naik turunnya produksi akan mempengaruhi harga jual cabai merah di pasar. Naik turunnya harga jual dapat mempengaruhi minat petani dalam berusahatani cabai merah, sehingga berdampak pada produksi yang dihasilkan.

Kabupaten Lampung Selatan merupakan sentra produksi cabai merah di Provinsi Lampung. Produksi cabai merah di Kabupaten Lampung Selatan tahun 2017 sebesar 15.918 ton dengan produktivitas sebesar 14,25 ton/ha (BPS Provinsi Lampung 2018). Kecamatan Way Sulan merupakan sentra produksi cabai merah di Kabupaten Lampung Selatan dengan produksi pada tahun 2017 sebesar 1.788 ton dan produktivitas sebesar 10,22 ton/ha (BPS Kabupaten Lampung Selatan 2018). Akan tetapi, produktivitas tersebut menempati urutan ketiga terendah di Kabupaten Lampung Selatan. Hal ini mengindikasikan adanya masalah dalam usahatani cabai merah di Kecamatan Way Sulan. Berdasarkan hasil survey, dapat diidentifikasi adanya masalah tersebut, diantaranya harga cabai merah berfluktuasi, sistem produksi cabai merah bergantung pada musim, dan usahatani cabai merah melibatkan petani skala kecil.

Harga jual yang berfluktuasi akan mempengaruhi besarnya pendapatan yang diterima petani dan 
berdampak pada risiko harga jual yang harus diterima petani (Heriani, Zakaria, dan Soelaiman 2013). Selain itu, adanya fluktuasi produksi yang disebabkan oleh sistem produksi yang bergantung pada musim juga menyebabkan petani dihadapkan pada risiko produksi. Risiko produksi dan harga jual akan mempengaruhi besarnya risiko pendapatan yang diterima petani. Oleh karena itu, penelitian ini bertujuan untuk mengetahui pendapatan usahatani cabai merah di Kecamatan Way Sulan Kabupaten Lampung Selatan, mengetahui besarnya risiko usahatani cabai merah di Kecamatan Way Sulan Kabupaten Lampung Selatan, dan mengetahui hubungan risiko dengan pendapatan usahatani cabai merah di Kecamatan Way Sulan Kabupaten Lampung Selatan.

\section{METODE PENELITIAN}

Penelitian ini dilakukan dengan metode survei, di Kecamatan Way Sulan, Kabupaten Lampung Selatan. Pemilihan lokasi penelitian ditentukan secara sengaja (purposive), dengan pertimbangan bahwa Kecamatan Way Sulan sebagai daerah penghasil cabai merah terbesar di Kabupaten Lampung Selatan. Penentuan sampel dilakukan dengan metode acak sederhana (simple random sampling) menggunakan rumus Isaac dan Michael dalam Ismail (2018), yang melibatkan 56 petani. Jumlah petani responden selanjutnya diproporsikan ke dalam empat desa, yang terdiri dari 36 responden di Desa Talang Way Sulan, 11 responden di Desa Pamulihan, 5 responden di Desa Sumber Agung, dan 4 responden di Desa Purwodadi.

Jenis data yang digunakan dalam penelitian ini adalah data kuantitatif. Data primer dikumpulkan dari hasil turun lapang menggunakan kuesioner dan pengamatan di lapangan. Data primer yang diperoleh dari petani adalah data produksi dan harga cabai merah dalam lima musim tanam tahun 2014-2018 (MT, MT -1, MT -2, MT -3, dan MT 4), input/masukan apa saja yang digunakan, serta biaya yang dikeluarkan dalam usahatani cabai merah dalam satu musim tanam (MT). Data sekunder meliputi data-data lainnya yang mendukung penelitian ini. Data sekunder diperoleh dari literatur seperti penelitian terdahulu, data BPS, BPP Kecamatan Way Sulan, dan lembaga/instansi terkait, laporan-laporan, dan pustaka lainnya yang berkaitan dengan penelitian.

Pendapatan usahatani cabai merah dihitung menggunakan rumus Rahim dan Hastuti (2008), sebagai berikut :
$\pi=\mathrm{TR}-\mathrm{TC}$

Keterangan :

$\pi \quad=$ Pendapatan bersih (Rp)

$\mathrm{TR}=$ Total penerimaan $(\mathrm{Rp})$

$\mathrm{TC}=$ Total biaya $(\mathrm{Rp})$

Pendapatan usahatani selanjutnya dianalisis dengan menghitung nisbah antara penerimaan dengan biaya menggunakan rumus Suratiyah (2015), sebagai berikut :

$\mathrm{R} / \mathrm{C}=\frac{\mathrm{TR}}{\mathrm{TC}}$

Keterangan :

$\mathrm{R} / \mathrm{C}=$ Nisbah penerimaan total dengan biaya total

$\mathrm{TR}=$ Total penerimaan $(\mathrm{Rp})$

$\mathrm{TC}=$ Total biaya $(\mathrm{Rp})$

Terdapat tiga kategori penilaian $\mathrm{R} / \mathrm{C}$, antara lain :

Nilai $R / C>1$, maka usahatani untung.

Nilai $\mathrm{R} / \mathrm{C}<1$, maka usahatani rugi.

Nilai $\mathrm{R} / \mathrm{C}=1$, maka usahatani berada pada titik impas/break event point.

Risiko usahatani dihitung menggunakan data produksi dan harga cabai merah, dalam penelitian ini digunakan lima musim tanam. Biaya produksi dalam penelitian ini mengacu pada biaya produksi MT tahun 2018. Besar kecilnya risiko dihitung menggunakan rumus Pappas dan Hirschey (1995), sebagai berikut :

$\mathrm{CV}=\frac{\sigma}{\mathrm{E}}$

Keterangan:

$\mathrm{CV}=$ Koefisien variasi

$\sigma \quad=$ Simpangan baku

$\mathrm{E}=$ Expected produksi, harga, pendapatan

Nilai CV berbanding lurus dengan risiko yang dihadapi petani cabai merah, artinya semakin besar nilai CV yang diperoleh, maka semakin besar pula risiko yang harus ditanggung petani dan sebaliknya. Nilai batas bawah (L) menunjukkan nilai nominal keuntungan terendah yang mungkin diterima oleh petani. Rumus batas bawah (L) menurut Kadarsan (1995) yaitu :

$\mathrm{L}=\mathrm{E}-2 \sigma$

Keterangan:

$\mathrm{L}=$ Batas bawah 
$\mathrm{E} \quad=$ Expected produksi, harga, pendapatan

$$
\sigma \quad=\text { Simpangan baku }
$$

Menurut Kadarsan (1995), semakin tinggi risiko yang akan dihadapi petani, semakin tinggi pula hasil atau keuntungan yang diharapkan. Namun Hanafi (2014), menyatakan bahwa hubungan antara risiko dengan tingkat keuntungan bersifat negatif. Oleh karena itu, untuk mengetahui bagaimana hubungan antara besarnya risiko dengan tingkat keuntungan yang diterima petani, dilakukan uji hipotesis menggunakan korelasi Product Moment Pearson.

Korelasi Product Moment Pearson digunakan untuk mencari hubungan dan membuktikan hipotesis hubungan dua variabel, jika data kedua variabel bertentuk interval atau rasio dan sumber data dari dua variabel/lebih adalah sama. Nilai korelasi (r) adalah 0 sampai 1 atau 0 sampai -1 (untuk hubungan negatif, semakin mendekati 1 atau -1, maka hubungan yang terjadi semakin erat. Rumus untuk mengukur korelasi Pearson menurut Sujarweni dan Endrayanto (2012), yaitu :

$$
r_{x y}=\frac{\sum x y}{\sqrt{\sum x^{2} \sqrt{\sum y^{2}}}}
$$

Keterangan:

$$
\begin{array}{ll}
\mathrm{r}_{\mathrm{xy}} & =\text { Korelasi antara variabel } \mathrm{x} \text { dan } \mathrm{y} \\
\mathrm{x} & =\left(\mathrm{x}_{\mathrm{i}}-\bar{x}\right) \\
\mathrm{y} & =\left(\mathrm{y}_{\mathrm{i}}-\bar{y}\right)
\end{array}
$$

Priyatno (2012) menyatakan, untuk melihat hubungan antara dua variabel tersebut positif atau negatif, maka dapat dilihat pada koefisien korelasi. Jika koefisien positif, maka hubungan positif, artinya jika variabel $\mathrm{X}$ naik maka variabel $\mathrm{Y}$ akan meningkat. Jika koefisien negatif, maka hubungan negatif, artinya jika variabel naik maka variabel $\mathrm{Y}$ turun, kemudian untuk mengetahui apakah hubungannya signifikan atau tidak, maka dilakukan uji signifikansi. Pengujian tingkat signifikansi dilakukan dengan menggunakan uji dua sisi (two tailed).

\section{HASIL DAN PEMBAHASAN}

Hasil penelitian menunjukkan bahwa sebesar 55 persen umur petani cabai merah di Kecamatan Way Sulan berada pada usia $\geq 45$ tahun. Hal ini sejalan dengan hasil Analisis Tematik Sensus Pertanian 2013 Subsektor Hortikultura menurut BPS (2015), mayoritas petani cabai merah termasuk dalam kategori lanjut usia menurut ukuran Departemen Kesehatan Republik Indonesia. Tingkat pendidikan petani cabai merah di Kecamatan Way Sulan masih tergolong rendah, karena sebesar 52 persen petani di Kecamatan Way Sulan adalah lulusan SMP. Mayoritas pengalaman petani dalam usahatani cabai merah berada pada interval 6-10 tahun, yaitu sebesar 48 persen. Pekerjaan sampingan petani cabai merah didominasi dalam bidang non farm, yaitu sebesar 46 persen. Jumlah tanggungan keluarga petani cabai merah di Kecamatan Way Sulan berada pada interval 3-4 orang dengan persentase sebesar 71 persen.

\section{Penggunaan faktor produksi}

Lahan merupakan tempat berlangsungnya proses produksi. Luas lahan dapat memengaruhi besarnya pendapatan usahatani. Mayoritas petani cabai merah di Kecamatan Way Sulan adalah petani gurem dengan persentase 71 persen, petani memiliki luas lahan $0,25-0,50$ hektare. Status kepemilikan lahan di Kecamatan Way Sulan adalah lahan sewa dengan persentase sebesar 71,43 persen. Usahatani cabai merah di Kecamatan Way Sulan bersifat komersial. Alasan petani memilih usahatani cabai merah dibandingkan usahatani yang lain karena lebih menguntungkan. Hal ini karena harga jual cabai merah lebih mahal dan umur tanaman lebih lama.

Benih cabai merah yang digunakan oleh petani di Kecamatan Way Sulan adalah benih hibrida varietas Lado F1, dengan rata-rata penggunaan benih sebesar 133,93 gram per hektare. Penggunaan benih cabai merah belum sesuai anjuran, karena menurut Swastika, Pratama, Hidayat, dan Andri (2017), kebutuhan benih cabai setiap hektare pertanaman adalah 150 - 300 gram dengan daya tumbuh lebih dari 90 persen. Petani di Kecamatan Way Sulan menggunakan enam jenis pupuk, yaitu pupuk kandang, NPK mutiara, phonska, SP-36, dan dolomit. Keenam jenis pupuk tersebut belum memenuhi standar pemupukan berimbang menurut anjuran PT Petrokimia Gresik (2019), sehingga diperlukan pemahaman bagi petani mengenai dosis pupuk dan pemupukan agar produksi dapat meningkat. Terdapat 11 macam pestisida yang digunakan petani, jenis pestisida yang paling banyak digunakan oleh petani adalah insektisida dengan merk dagang Starban. Hal ini karena organisme yang paling banyak menyerang adalah hama, seperti ulat grayak, kupu-kupu kecil, dan lalat buah. Jenis mulsa yang digunakan oleh petani di Kecamatan Way Sulan adalah mulsa plastik hitam perak (MPHP) dengan ukuran $400 \mathrm{~m}$ 
x $600 \mathrm{~m}$. Rata-rata penggunaan mulsa plastik sebesar 11,82 roll per hektare. Jenis ajir yang digunakan petani adalah ajir bambu dengan ratarata penggunaan sebesar $13.435,71$ batang per hektare. Penggunaan tenaga kerja tertinggi dalam usahatani cabai merah di Kecamatan Way Sulan adalah kegiatan panen, dengan jumlah TKDK sebesar 50,64 HKP dan TKLK sebesar 108,36 HKP per hektare.

\section{Biaya usahatani}

Biaya usahatani terdiri menjadi dua macam, yaitu biaya tunai dan biaya diperhitungkan. Komponen biaya usahatani terdiri dari pembelian benih, pupuk, pestisida, mulsa, dan pengeluaran lain. Persentase tertinggi dari biaya tunai yang dikeluarkan oleh petani di Kecamatan Way Sulan adalah biaya tenaga kerja luar keluarga (TKLK) yaitu sebesar 24,95 persen. Hasil penelitian sejalan dengan penelitian Chonani (2014), yang menyatakan bahwa TKLK merupakan biaya tunai tertinggi dalam usahatani cabai merah di Kecamatan Metro Kibang Kabupaten Lampung Timur.

Komponen biaya diperhitungkan terdiri dari biaya tenaga kerja dalam keluarga (TKDK), sewa lahan (jika lahan milik sendiri), dan nilai penyusutan. Persentase tertinggi untuk biaya diperhitungkan adalah biaya TKDK yaitu sebesar 63,20 persen. Dengan demikian, biaya tertinggi usahatani cabai merah di Kecamatan Way Sulan adalah biaya tenaga kerja. Hasil Analisis Tematik Sensus Pertanian 2013 Subsektor Hortikultura mendukung penelitian ini, bahwa secara umum pengeluaran untuk biaya tenaga kerja pada komoditas cabai merah merupakan komponen biaya yang memiliki proporsi terbesar.

\section{Produksi dan penerimaan}

Kegiatan usahatani cabai merah memerlukan waktu selama 100 - 120 hari hingga panen. Panen cabai merah dilakukan sebanyak 16 kali panen, dengan produksi dan harga jual yang berbedabeda. Periode panen di Kecamatan Way Sulan dilakukan pada bulan November - Desember. Petani melakukan kegiatan panen setiap 2-5 hari sekali dengan menyesuaikan tingkat kematangan buah. Hasil panen tertinggi berada pada petik ke-7 sampai 9. Hal ini dapat dilihat pada Gambar 1. Gambar 1 menunjukkan panen pada petik ke-7 merupakan puncak hasil produksi, selanjutnya hasil produksi semakin menyusut hingga petik ke16.

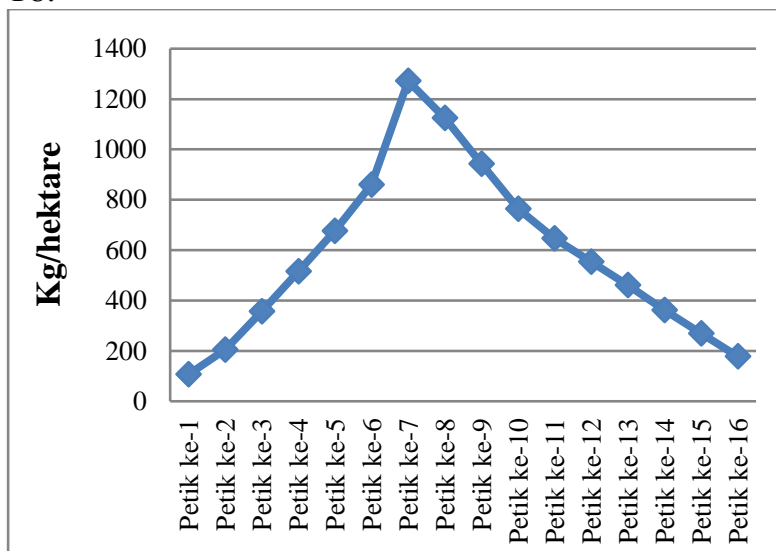

Gambar 1. Rata-rata produksi cabai merah di Kecamatan Way Sulan, per hektare

Rata-rata produksi total cabai merah di Kecamatan Way Sulan sebesar 9.288,59 kg per hektare. Harga jual setiap waktu panen berbeda-beda. Rata-rata harga jual cabai merah pada MT lebih rendah dibandingkan musim tanam sebelumnya. Rata-rata harga jual cabai merah pada MT sebesar Rp15.769,64 per kg. Rata-rata harga jual cabai merah pada petik pertama sebesar Rp20.035,71 per kg menjadi Rp11.080,36 per kg pada petik ke-16.

Hasil penelitian sesuai dengan data sekunder berdasarkan statistik harga produsen pertanian di Kabupaten Lampung Selatan menurut BPS Provinsi Lampung (2019), bahwa rata-rata harga cabai merah di tingkat produsen menurun dari Rp41.000,00 per kg pada bulan Mei 2018 menjadi Rp20.035,71 per kg di bulan Desember 2018.

\section{Analisis Pendapatan Usahatani Cabai Merah}

Analisis pendapatan bertujuan untuk mengetahui keberhasilan usahatani cabai merah, apakah menguntungkan atau tidak. Pendapatan usahatani cabai merah dalam penelitian ini dianalisis menggunakan analisis revenue of cost ratio $(\mathrm{R} / \mathrm{C})$ menggunakan rumus Suratiyah (2015).

Penerimaan dihitung berdasarkan hasil kali antara produksi dengan harga jual dan pendapatan usahatani diperoleh dari hasil pengurangan antara penerimaan dengan biaya produksi. Penelitian ini menganalisis pendapatan yang diperoleh petani pada musim tanam terakhir yaitu pada periode Juli sampai Desember 2018. Berdasarkan hasil analisis, diperoleh nisbah penerimaan terhadap biaya yang dapat dilihat pada Tabel 1 . 
Jurnal Ilmu Ilmu Agribisnis: Journal of Agribusiness Science, 9(2), Mei 2021

Tabel 1. Analisis usahatani cabai merah di Kecamatan Way Sulan pada MT 2018, per hektare

\begin{tabular}{|c|c|c|c|c|}
\hline Uraian & Satuan & Jumlah & Harga (Rp) & Nilai (Rp) \\
\hline Penerimaan & $\mathrm{Rp}$ & & & $146.477 .735,68$ \\
\hline Produksi & $\mathrm{Kg}$ & $9.288,59$ & $15.769,64$ & $146.477 .735,68$ \\
\hline \multicolumn{5}{|l|}{ Biaya produksi } \\
\hline \multicolumn{5}{|l|}{ I. Biaya tunai } \\
\hline Benih & Bks & 13,39 & $147.118,75$ & $1.970 .340,40$ \\
\hline Pupuk kandang & $\mathrm{Kg}$ & $9.342,26$ & 138,79 & $1.296 .627,54$ \\
\hline Pupuk NPK Mutiara & $\mathrm{Kg}$ & 252,40 & $9.826,52$ & $2.480 .201,41$ \\
\hline Pupuk Phonska & $\mathrm{Kg}$ & 223,33 & $2.576,88$ & $575.502,08$ \\
\hline Pupuk Phonska & $\mathrm{Kg}$ & 161,10 & $2.910,89$ & $468.948,30$ \\
\hline Pupuk KCl & $\mathrm{Kg}$ & 164,58 & $6.223,08$ & $1.024 .214,74$ \\
\hline Pupuk Dolomit & $\mathrm{Kg}$ & 390,95 & 879,00 & $343.647,14$ \\
\hline Pestisida & $\mathrm{Rp}$ & & & $3.175 .677,08$ \\
\hline Mulsa & Roll & 11,83 & $455.625,00$ & $5.386 .138,39$ \\
\hline Ajir & Batang & $13.435,71$ & 400,00 & $5.374 .285,71$ \\
\hline Tali raffia & Roll & 30,43 & $7.000,00$ & $212.991,67$ \\
\hline TKLK & HKP & 182,74 & $60.000,00$ & $10.964 .482,14$ \\
\hline Pajak & $\mathrm{Rp} / \mathrm{MT}$ & & & $14.226,19$ \\
\hline Sewa lahan & $\mathrm{Rp} / \mathrm{MT}$ & & & $8.571 .428,57$ \\
\hline Biaya sewa sumur bor & $\mathrm{Rp} / \mathrm{MT}$ & & & $1.717 .428,57$ \\
\hline Biaya listrik & $\mathrm{Rp} / \mathrm{MT}$ & & & $155.505,94$ \\
\hline Biaya bensin & $\mathrm{Rp} / \mathrm{MT}$ & & & $1.042 .857,14$ \\
\hline Total biaya tunai & $\mathrm{Rp}$ & & & $44.774 .503,06$ \\
\hline \multicolumn{5}{|l|}{ II. Biaya diperhitungkan } \\
\hline TKDK & HKP & 119,61 & $60.000,00$ & 7.176.610,71 \\
\hline Sewa lahan & $\mathrm{Rp} / \mathrm{MT}$ & & & $3.442 .857,14$ \\
\hline enyusutan alat & $\mathrm{Rp} / \mathrm{MT}$ & & & $736.500,59$ \\
\hline Total biaya diperhitungkan & $\mathrm{Rp}$ & & & $11.355 .968,45$ \\
\hline III. Biaya total & $\mathrm{Rp}$ & & & $56.130 .471,50$ \\
\hline \multicolumn{5}{|l|}{ Pendapatan } \\
\hline Pendapatan atas biaya tunai & $\mathrm{Rp}$ & & & $101.703 .232,62$ \\
\hline Pendapatan atas biaya total & $\mathrm{Rp}$ & & & $90.347 .264,18$ \\
\hline $\mathrm{R} / \mathrm{C}$ atas biaya tunai & & & & 3,27 \\
\hline $\mathrm{R} / \mathrm{C}$ atas biaya total & & & & 2,61 \\
\hline
\end{tabular}

Tabel 1 menunjukkan pendapatan atas biaya tunai di Kecamatan Way Sulan pada MT sebesar Rp101.703.232,62 per hektare, sehingga diperoleh nisbah penerimaan sebesar 3,27 atas biaya tunai. Artinya, setiap Rp100,00 biaya tunai yang dikeluarkan petani, maka petani akan mendapatkan penerimaan sebesar Rp327,00. Hasil Analisis Tematik Sensus Pertanian 2013 Subsektor Hortikultura mendukung penelitian ini, yang memberikan informasi bahwa besarnya pendapatan usahatani cabai merah sebesar Rp63.690.000,00 dengan nilai $\mathrm{R} / \mathrm{C}$ sebesar 1,33. Oleh karena itu, dapat disimpulkan bahwa usahatani cabai merah menguntungkan, karena R/C >1.

\section{Analisis Risiko Usahatani Cabai Merah}

Risiko usahatani dalam penelitian ini terdiri dari risiko produksi, harga, dan pendapatan selama lima musim tanam, yaitu tahun 2014 - 2018. Data produksi dan harga diperoleh dari hasil wawancara dengan petani menggunakan metode recall.

Penggunaan input pada MT - 1 sampai MT -4 tidak dapat diketahui, karena petani sudah tidak ingat dan tidak semua petani melakukan pembukuan dalam kegiatan usahatani, sehingga biaya usahatani dianggap sama dengan biaya pada MT 2018. Hal tersebut menjadi keterbatasan dalam penelitian ini.

Risiko usahatani terjadi akibat adanya variasi atau fluktuasi pada produksi maupun harga jual, sehingga menimbulkan ketidakpastian pendapatan yang diterima petani. Fluktuasi produksi terjadi dapat disebabkan oleh beberapa faktor, diantaranya faktor serangan OPT dan cuaca ekstrem. Fluktuasi produksi cabai merah selama lima musim tanam di Kecamatan Way Sulan dapat dilihat pada Gambar 2.

Gambar 2 menunjukkan bahwa rata-rata produktivitas terendah di Kecamatan Way Sulan selama lima musim tanam berada pada MT -2 atau tahun 2016 dengan nilai produktivitas sebesar $8.002,14 \mathrm{~kg}$ per hektare. Hasil penelitian sejalan dengan data sekunder menurut BPS Kecamatan Way Sulan (2017), bahwa rata-rata produktivitas cabai merah terendah di Kecamatan Way Sulan terjadi pada tahun 2016, yaitu sebesar 8.845,68 kg perhektare. 
Jurnal Ilmu Ilmu Agribisnis: Journal of Agribusiness Science, 9(2), Mei 2021

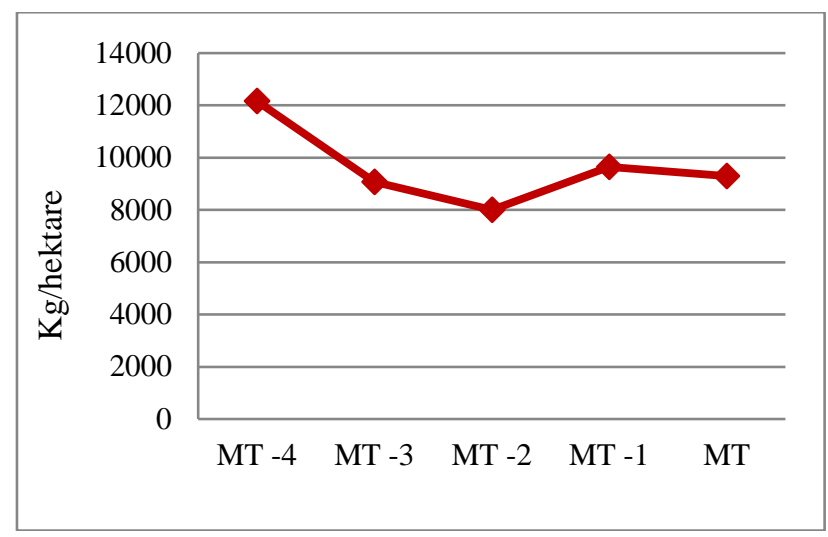

Gambar 2. Fluktuasi produktivitas cabai merah.

Berdasarkan penelitian yang telah dilakukan, terjadinya fluktuasi produksi disebabkan serangan OPT dan cuaca ekstrem. Pada dasarnya, cabai merah merupakan tanaman yang rentan terhadap OPT dan cuaca ekstrem. Keduanya menjadi peluang yang dapat merugikan petani, karena dampak dari cuaca ekstrem adalah meningkatnya serangan hama dan penyakit pada tanaman cabai merah. Penyakit yang paling sering menyerang tanaman cabai merah adalah patek, jamur, dan busuk buah, sedangkan hama yang paling sering menyerang adalah kutu daun, ulat, kupu-kupu kecil, thrips, dan lalat buah.

Upaya yang dapat dilakukan oleh petani adalah menggunakan berbagai macam pestisida untuk menekan serangan OPT, karena cuaca tidak dapat dicegah dan diprediksi. Besar kecilnya intensitas pemberian pestisida tentunya akan mempengaruhi biaya produksi yang dikeluarkan petani, sehingga petani dihadapkan pada peluang terjadinya kerugian. Upaya yang dilakukan petani adalah tetap melakukan penyemprotan secara rutin, karena jika dibiarkan akan mengakibatkan gagal panen 100 persen.

Risiko harga terjadi karena adanya fluktuasi harga jual cabai merah selama lima musim terakhir. Fluktuasi harga jual cabai merah di Kecamatan Way Sulan dapat dilihat pada Gambar 3.

Gambar 3 menunjukkan harga jual tertinggi berada pada MT -4 atau tahun 2014 dengan nilai sebesar Rp27.750,00 per kg. Hasil penelitian sesuai dengan data sekunder berdasarkan statistik harga produsen di Kabupaten Lampung Selatan menurut BPS Provinsi Lampung (2014), bahwa rata-rata harga jual cabai merah di tingkat produsen periode November - Desember tahun 2014 di Kabupaten Lampung Selatan merupakan harga tertinggi, yaitu sebesar Rp32.833,33 per kg.

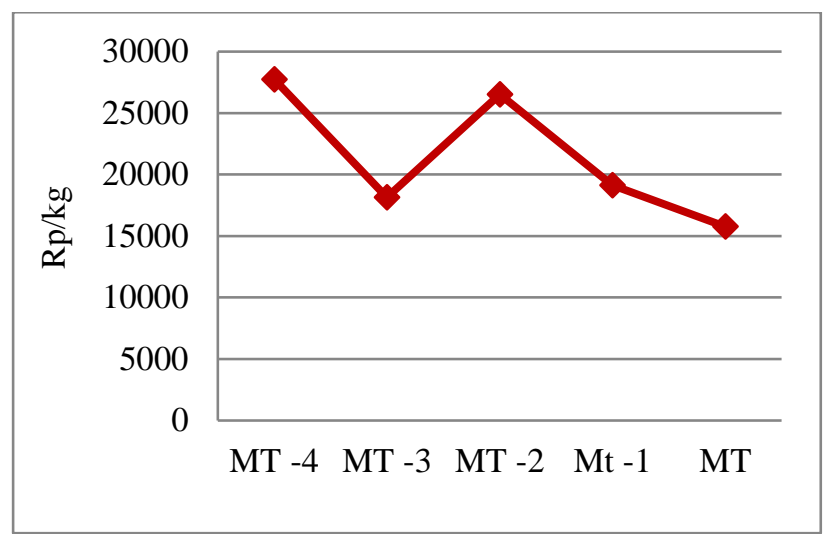

Gambar 3. Fluktuasi harga jual cabai merah.

Terjadinya lonjakan harga pada MT -4 atau tahun 2014 disebabkan karena kekurangan pasokan. Jika dilihat dari fluktuasi produksi di Kcamatan Way Sulan, jumlah produksi pada MT -4 tahun 2014 merupakan produksi terendah dibandingkan musim tanam lainnya. Jumlah produksi pada MT -4 tahun 2014 sebesar 287.900,00 kg. Produktivitas pada MT -4 tertinggi disebabkan luas lahan cabai merah di Kecamatan Way Sulan masih kecil yaitu 20 hektare, sehingga harga jual cabai merah menjadi tertinggi pada MT -4 atau tahun 2014. Selain itu, terjadi kemarau panjang pada bulan Oktober 2014 sampai Desember 2014, bahkan masih berjalan hingga bulan Januari 2015, sehingga harga cabai merah melonjak, mencapai Rp39.000,00 per kg pada bulan Desember 2014 menurut BPS Provinsi Lampung (2014).

Jika dilihat dari Gambar 3, harga jual cabai merah pada MT merupakan harga terendah dibandingkan musim tanam sebelumnya. Berdasarkan wawancara dengan petani, hal ini terjadi karena cuaca yang semakin sulit diprediksi, sehingga meningkatkan populasi serangan organisme pengganggu tanaman (OPT). Hal tersebut berdampak pada kualitas cabai merah yang dihasilkan, selain itu jumlah pasokan saat panen raya juga menjadi faktor menurunnya harga jual. Jumlah pasokan cabai merah yang tersedia di Lampung maupun luar Lampung dapat mempengaruhi harga jual yang diterima petani.

Hasil perhitungan risiko usahatani dapat dilihat pada Tabel 2. Tabel 2 menunjukkan bahwa nilai rata-rata (mean) produksi cabai merah yang diharapkan sebesar 9.634,16 kg per hektare, sedangkan fluktuasi produksi yang mungkin dihadapi petani sebesar $1.602,21 \mathrm{~kg}$ per hektare. Peluang terjadinya kerugian dapat dilihat dari nilai koefisien variasi $(\mathrm{CV})$ produksi sebesar 0,17 . 
Tabel 2. Analisis risiko usahatani cabai merah

\begin{tabular}{|c|c|c|c|}
\hline Uraian & $\begin{array}{c}\text { Produksi } \\
\text { (kg/ha) }\end{array}$ & $\begin{array}{c}\text { Harga } \\
(\mathrm{Rp} / \mathrm{kg})\end{array}$ & Pendapatan (Rp) \\
\hline Mean $(\mathrm{E})$ & $9.634,16$ & $21.468,21$ & $164.406 .188,70$ \\
\hline $\begin{array}{l}\text { Simp. } \\
\text { baku }(\sigma)\end{array}$ & $1.602,21$ & $5.449,01$ & $76.662 .180,92$ \\
\hline $\begin{array}{l}\text { Koef. Var } \\
\text { (CV) }\end{array}$ & 0,17 & 0,25 & 0,46 \\
\hline $\begin{array}{l}\text { Batas } \\
\text { bawah (L) }\end{array}$ & $6.429,74$ & $10.570,20$ & $11.081 .826,87$ \\
\hline
\end{tabular}

Hal ini berarti setiap $100 \mathrm{~kg}$ cabai merah yang diharapkan, petani menanggung risiko produksi sebesar $17 \mathrm{~kg}$, dan nilai batas bawah (L) sebesar $6.429,74 \mathrm{~kg}$, artinya kemungkinan produksi terendah per usahatani adalah $6.429,74 \mathrm{~kg}$.

Nilai mean harga atau harga yang diharapkan adalah sebesar Rp21.468,21 per kg, sedangkan fluktuasi harga yang mungkin terjadi sebesar $\mathrm{Rp}$ $5.449,01$ per kg. Peluang terjadinya kerugian yang harus diterima petani sebesar 0,25 . Artinya setiap Rp100,00 harga jual cabai merah yang diharapkan, petani menanggung risiko harga sebesar $\mathrm{Rp} 25,00$. Nilai batas bawah (L) harga sebesar Rp10.570,20 per $\mathrm{kg}$, artinya harga jual terendah yang masih mungkin diterima petani per usahatani adalah sebesar Rp10.570,20 per kg.

Nilai mean pendapatan yang diharapkan adalah sebesar Rp164.406.188,70 per hektare, sedangkan fluktuasi pendapatan yang dihadapi oleh petani sebesar Rp76.662.180,92 per hektare. Peluang terjadinya kerugian yang harus ditanggung oleh petani sebesar 0,46, artinya setiap Rp100 pendapatan yang diharapkan, petani menanggung risiko pendapatan sebesar Rp 46,00. Nilai batas bawah pendapatan (L) menunjukkan bahwa usahatani cabai merah masih menguntungkan, karena nilai L $>0$ yaitu sebesar Rp11.081.826,87 per hektare, artinya pendapatan terendah yang masih mungkin diterima petani sebesar Rp11.081.826,87 per hektare per usahatani. Dengan demikian, dapat disimpulkan bahwa usahatani cabai merah di Kecamatan Way Sulan masih menguntungkan untuk dijalankan karena nilai $\mathrm{CV}<0,50$ dan $\mathrm{L}>0$.

\section{Analisis Hubungan Risiko dengan Pendapatan Usahatani Cabai Merah}

Analisis hubungan risiko dengan pendapatan, digunakan analisis korelasi Product Moment Pearson. Hasil uji korelasi Pearson dapat dilihat pada Tabel 3. Tabel 3 menunjukkan bahwa terdapat hubungan antara pendapatan dengan risiko usahatani cabai merah. Hal ini ditunjukkan dari nilai signifikansi ( $\rho$-value) sebesar 0,002. Nilai koefisien korelasi sebesar 0,409 menunjukkan bahwa hubungan yang terjadi adalah positif dengan tingkat keeratan yaitu cukup erat menurut Silaen dan Widiyono (2013), artinya hubungan yang terjadi searah, semakin besar variabel $\mathrm{X}$ maka semakin besar variabel Y. Dengan demikian, semakin tinggi tingkat risiko, maka semakin tinggi pula pendapatan yang diharapkan petani cabai merah di Kecamatan Way Sulan, sehingga $\mathrm{H}_{0}$ diterima pada tingkat kepercayaan 99 persen.

Hasil penelitian ini sesuai dengan pernyataan Kadarsan (1995), yang menyatakan bahwa semakin tinggi risiko yang akan dihadapi petani, semakin tinggi pula hasil atau keuntungan yang diharapkan. Penelitian ini juga didukung oleh pernyataan Pappas dan Hirschey (1995) bahwa apabila tingkat risiko meningkat, para investor umumnya menuntut pengembalian yang lebih tinggi untuk mengompensasikan peningkatan risiko tersebut. Arsyad (2012) juga menyatakan bahwa biasanya perusahaan dapat meningkatkan nilai laba harapan dengan melakukan investasi yang berisiko lebih tinggi. Berdasarkan pernyataan ketiga ahli di atas, maka dapat disimpulkan bahwa semakin tinggi risiko yang ditanggung oleh petani, maka petani mengharapkan pendapatan yang semakin tinggi pula.

Hasil penelitian tidak sejalan dengan pernyataan menurut Hanafi (2014) yang menyatakan bahwa hubungan antara risiko dengan tingkat keuntungan bersifat negatif. Menurut Hanafi (2014), risiko yang diambil organisasi terlalu tinggi (jika nilai probabilitas $>0,5$ ), maka penambahan risiko akan berdampak negatif terhadap organisasi, sedangkan hasil penelitian menunjukkan nilai koefisien variasi pada risiko pendapatan sebesar 0,46. Dengan demikian risiko usahatani cabai merah di Kecamatan Way Sulan tergolong rendah.

Tabel 3. Hasil uji korelasi Pearson

\begin{tabular}{lcr}
\hline & $\begin{array}{c}\text { Correlations } \\
\text { Risiko }\end{array}$ & Pendapatan \\
\hline Risiko Pearson & 1,000 & $0,409 * *$ \\
Correlation & & \\
Sig. (2-tailed) & & 0,002 \\
$\mathrm{~N}$ & 56,000 & 56,000 \\
PendapatanPearson & $0,409 * *$ & \\
Correlation & & \\
Sig. (2-tailed) & 0,002 & 56,000 \\
$\mathrm{~N}$ & 56,000 & \\
$* *$. Correlations is significant at the 0.01 level (2-tailed).
\end{tabular}




\section{KESIMPULAN}

Berdasarkan penelitian yang telah dilakukan, dapat disimpulkan bahwa usahatani cabai merah di Kecamatan Way Sulan Kabupaten Lampung Selatan menguntungkan karena R/C $>1$. Risiko usahatani cabai merah di Kecamatan Way Sulan tergolong rendah, karena nilai $\mathrm{CV}<0,50$, sehingga masih menguntungkan untuk dijalankan dengan nilai batas bawah $(\mathrm{L})>0$. Terdapat hubungan positif antara risiko dengan pendapatan usahatani cabai merah di Kecamatan Way Sulan Kabupaten Lampung Selatan. Hal ini berarti semakin tinggi tingkat risiko yang dihadapi, maka semakin tinggi tingkat pendapatan yang diharapkan oleh petani.

\section{DAFTAR PUSTAKA}

Arsyad L. 2012. Ekonomi Manajerial : Ekonomi Mikro Terapan untuk Manajemen Bisnis Edisi Keempat. Universitas Gadjah Mada. Yogyakarta.

BPS [Badan Pusat Statistik] Provinsi Lampung. 2019. Provinsi Lampung dalam Angka. http://lampung.bps.go.id/publication/2019/08/ 16/provinsi-lampung-dalam-angka-2019 [27 Agustus 2019].

BPS [Badan Pusat Statistik] Provinsi Lampung. 2014. Statistik Harga Produsen Pertanian Provinsi Lampung (Subsektor Tanaman Pangan, Hortikultura, Tanaman Perkebunan Rakyat, Peternakan, dan Perikanan) Tahun 2014. http://lampung.bps.go.id/publication/ 2015/04/30/statistik-harga-produsenpertanian-subsektor-tanaman-panganhortikultura-dan-tanaman-perkebunan-rakyat2014 [10 Agustus 2019].

BPS [Badan Pusat Statistik] Kabupaten Lampung Selatan. 2018. Kabupaten Lampung Selatan dalam Angka 2017. https://lampungselatankab.bps.go.id/publicati on/2017/08/12/0376f3128d6a32ab86f43a77/k abupaten-lampung-selatan-dalam-angka2017.html [27 September 2018].

BPS [Badan Pusat Statistik] Kecamatan Way Sulan. 2017. Kecamatan Way Sulan dalam Angka 2016. https://lampungselatankab.bps.go.id/publicati on/2017/09/20/1014fd1af228e95c50ceebe3/ke camatan-way-sulan-dalam-angka-2017.html [September 2018].

BPS [Badan Pusat Statistik]. 2015. Efisiensi
Sistem Produksi dan Tataniaga Hortikultura; Analisis Tematik Sensus Pertanian (ST2013) Subsektor. http://docplayer.info/60201498/ Badan-pusat-statistik-analisis-tematikST2013-subsektor-efisiensi-produksitataniaga-hortikultura [10 Juni 2019].

Chonani SH, Prasmatiwi FE, dan Santoso H. 2014. Efisiensi produksi dan pendapatan usahatani cabai merah di Kecamatan Metro Kibang Kabupaten Lampung Timur : pendekatan fungsi produksi frontier. Jurnal Ilmu Ilmu Agribisnis, 2 (2) : 95-102. http://jurnal.fp.unila.ac.id/index.php/JIA/articl e/view/730 [1 November 2018].

Hanafi MM. 2014. Manajemen Risiko. Unit Penerbit dan Percetakan STIM YKPN. Yogyakarta.

Heriani N, Zakaria WA, dan Soelaiman A. 2013. Analisis keuntungan dan risiko usahatani tomat di Kecamatan Sumberejo Kabupaten Tanggamus. Jurnal Ilmu Ilmu Agribisnis, 1 $\begin{array}{lllll}(2) & : & 169 & - & 173 .\end{array}$ http://jurnal.fp.unila.ac.id/index.php/JIA/view /224 [1 November 2018].

Ismail F. 2018. Statistika untuk Penelitian Pendidikan dan Ilmu-ilmu Sosial. Prenamedia Group. Jakarta.

Kadarsan HW. 1995. Keuangan Pertanian dan Pembiayaan Perusahaan Agribisnis. Gramedia Pustaka Utama. Jakarta.

Pappas JM dan Hierschey M. 1995. Ekonomi Managerial Edisi Keenam Jilid II. Bina Rupa Aksara. Jakarta.

Petrokimia Gresik. 2019. Dosis Pemupukan Majemuk. http://www.petrokimiagresik.com/page/pupuk-majemuk [ 2 Agustus 2019].

Priyatno D. 2012. Cara Kilat Belajar Analisis Data dengan SPSS 20. Andi Offset. Yogyakarta.

Rahim dan Hastuti DRD. 2008. Pengantar, Teori, dan Kasus Ekonomika Pertanian. Penebar Swadaya. Jakarta.

Silaen S dan Widiyono. 2013. Metodologi Penelitian Sosial. In Media. Jakarta.

Sujarweni VW dan Endrayanto P. 2012. Statistika untuk Penelitian. Graha Ilmu. Yogyakarta.

Suratiyah K. 2015. Ilmu Usahatani Edisi Revisi. Penebar Swadaya. Jakarta.

Swastika S, Pratama D, Hidayat T, dan Andri KB. 2017. Teknologi Budidaya Cabai Merah. UR Press. Riau. 